\title{
Author Correction: Role of hypoxia in Diffuse Large B-cell Lymphoma: Metabolic repression and selective translation of HK2 facilitates development of DLBCL
}

\section{Kavita Bhalla ${ }^{1}$, Sausan Jaber ${ }^{2}$, Nanaji Nahid M. ${ }^{3}$, Karen Underwood ${ }^{4}$, Afshin Beheshti ${ }^{5}$, Ari} Landon ${ }^{6}$, Binny Bhandary ${ }^{1}$, Paul Bastian ${ }^{7}$, Andrew M. Evens ${ }^{5}$, John Haley ${ }^{8}$, Brian Polster ${ }^{2}$ \& Ronald B. Gartenhaus ${ }^{1,3}$

Correction to: Scientific Reports https://doi.org/10.1038/s41598-018-19182-8, published online 15 January 2018

The original version of this Article contained a typographical error in the spelling of the author Paul Bastian, which was incorrectly given as Paul Bastain.

In addition, the Acknowledgements section in this Article was incorrect:

"We thank Dr. Shambhu Bhat for performing correspondence analysis in this study and also for critical reading of the paper. We thank Dr. Girnun for providing HIF1 $\alpha$ construct and valuable suggestions for our study. We thank Dr. Elin Lehrmann and Dr. Kevin Becker for assistance with microarray data. We are grateful to Drs. Tony Passaniti and Michele Vitolo for critical reading of the manuscript. The research in R.B.G laboratory was supported in part by a Merit Review Award from the Department of Veterans Affairs and RO1-10019169 and RO1-10018832 from the NIH."

now reads:

"We thank Dr. Girnun for providing HIF1 $\alpha$ construct and valuable suggestions for our study. We thank Dr. Shambhu Bhat for performing correspondence analysis in this study and also for critical reading of the paper. We thank Dr. Elin Lehrmann and Dr. Kevin G. Becker (National Institute on Aging, National Institutes of Health Intramural Research Program) for undertaking microarray experiments, data analysis, and GEO data submission. We are grateful to Dr. Tony Passaniti and Dr. Michele Vitolo for critical reading of the manuscript. The research in R.B.G laboratory was supported in part by a Merit Review Award from the Department of Veterans Affairs, RO110019169 and RO1-10018832 from the NIH. This research was also supported in part by the Intramural research Program of the NIH, National institute on Aging."

These errors have now been corrected in the PDF and HTML versions of the Article. 
(i) Open Access This article is licensed under a Creative Commons Attribution 4.0 International License, which permits use, sharing, adaptation, distribution and reproduction in any medium or format, as long as you give appropriate credit to the original author(s) and the source, provide a link to the Creative Commons license, and indicate if changes were made. The images or other third party material in this article are included in the article's Creative Commons license, unless indicated otherwise in a credit line to the material. If material is not included in the article's Creative Commons license and your intended use is not permitted by statutory regulation or exceeds the permitted use, you will need to obtain permission directly from the copyright holder. To view a copy of this license, visit http://creativecommons.org/licenses/by/4.0/.

(C) The Author(s) 2018 